\title{
Lipid classes and fatty acids in plankton and settling matter during the spring bloom in a cold ocean coastal environment
}

\author{
Christopher C. Parrish*, Raymond J. Thompson, Don Deibel \\ Ocean Sciences Centre, Memorial University of Newfoundland, St. John's, Newfoundland and Labrador, A1C 5S7, Canada
}

\begin{abstract}
Lipid concentration and composition were measured in net-tow and sediment trap samples during the spring diatom bloom in Conception Bay, Newfoundland, to determine the quantity and quality of material settling from the upper mixed layer into the benthic food web. An experiment was also conducted to estimate trap accuracy and precision, in which trap poisoning was found to reduce bacterially mediated dissolution, but to increase variability in particulate lipid data. Total lipid concentrations in plankton reached a maximum of $6.3 \pm 2.5 \%$ dry weight (mean $\pm \mathrm{SD}$ ) at the height of the bloom in April. Bacterial fatty acid markers were at their lowest during the bloom period (2.0 to $2.8 \%$ of total fatty acids), while polyunsaturated fatty acids (PUFA) were at their highest from the beginning of the bloom onwards (44 to $53 \%$ ). The maximum fluxes of total lipids $\left(75 \pm 0.7 \mathrm{mg} \mathrm{m}^{-2} \mathrm{~d}^{-1}\right.$ ) in non-poisoned traps at $80 \mathrm{~m}$ depth occurred at the bloom maximum while those at $220 \mathrm{~m}(35 \pm$ $1.7 \mathrm{mg} \mathrm{m}^{-2} \mathrm{~d}^{-1}$ ) occurred $16 \mathrm{~d}$ later. The lipid and PUFA supply to the benthos was over 10 times that accumulated by important amphipod and mysid populations in Conception Bay. In the deep traps, PUFA were maintained at high levels ( 33 to $35 \%$ ) throughout the bloom period while bacterial markers were at their lowest (2.3 to $2.9 \%$ ). A comparison of fluxes showed that over half the PUFA survived transit from 80 to $220 \mathrm{~m}$ during the bloom period. These data indicate a rapid transfer of highly nutritious material to the benthos during the spring bloom in Conception Bay.
\end{abstract}

KEY WORDS: Lipids $\cdot$ Pigments $\cdot \mathrm{CHN} \cdot$ Net-tows $\cdot$ Sediment traps $\cdot$ Integrated fluxes

\section{INTRODUCTION}

Continental margins are particularly important for carbon cycling. Globally, $45 \%$ of buried organic matter occurs in shelf areas (Hedges \& Keil 1995). They are generally highly productive and the shallow water column reduces the opportunity for remineralization. More surface primary production reaches the seabed in shallower water (Tyler 1995) because particle fluxes decrease with depth as would be expected if particles are remineralized or disaggregated during settling (Asper et al. 1992). One question that remains is the variability in the nature of the material arriving in coastal sediments (Goñi et al. 2000).

Lipids are an important component of the productivity of shelf areas. They are carbon-rich with a very high energy value and are thus important metabolic fuels. Certain constituents of lipids such as polyunsaturated fatty acids (PUFA) are also essential nutrients for animals. Marine invertebrates require PUFA with between 2 and 6 double bonds for survival and growth (Xu et al. 1994, Pond et al. 1996, Milke et al. 2004).

In this lipid biogeochemistry study, cruises were undertaken in Conception Bay, Newfoundland, to sample a sinking spring bloom. Conception Bay is one of several large fjord-like bays on the Atlantic coast of Newfoundland. In order to measure the transfer of bloom material to the benthos we used sediment traps. While traps are the usual means of determining water column fluxes, problems with microbial activity and the use of poisons in traps (Lee et al. 1992) or with dissolution of trapped particles (Kortzinger et al. 1994) are 
well known. In a $3 \mathrm{~d}$ sediment trap deployment in Trinity Bay, Newfoundland, we had previously found that the amount of dissolved lipids could often be as high as one third the amount of particulate lipids in the bottom of sediment traps (Parrish 1998). However, by applying the principles of equilibrium chemistry we hypothesized that losses of lipid material due to dissolution would become proportionately less of a concern as the period of trap deployment increased (Budge \& Parrish 1998).

Our research site, Conception Bay, provides a unique opportunity to study cold ocean processes at midlatitudes. The inshore branch of the Labrador Current maintains sub-zero temperatures below $150 \mathrm{~m}$ yearround and surface waters are seasonally as cold (Stead \& Thompson 2003). However, modelling of over $10 \mathrm{yr}$ of biological and physical data has revealed that the timing of the initiation of the spring phytoplankton bloom is independent of temperature (Tian et al. 2003), while bacteria and especially zooplankton growth may be suppressed in the spring (Pomeroy et al. 1991). Consequently hyperbenthic and benthic animals are the recipients of significant portions of the productivity (Choe et al. 2003, Stead \& Thompson 2003). The quality of the settling material should be high, as polar microalgae produce high levels of PUFA (Skerratt et al. 1995, Henderson et al. 1998). Thus in this study we sought to measure the nature and quantity of spring bloom lipids produced at low temperatures and to determine their flux through the water column. We also evaluated the sampling process used to measure this lipid transfer to the benthos.

\section{MATERIALS AND METHODS}

Water and sediment trap samples were taken near the deepest part of Conception Bay in $248 \mathrm{~m}$ of water at 18 d intervals from 6 March to 9 July 1996 (Fig. 1). Conception Bay is $\sim 100 \mathrm{~km}$ long and $30 \mathrm{~km}$ wide, with a maximum depth of $\sim 300 \mathrm{~m}$ and a sill depth of $170 \mathrm{~m}$.

Water sampling. Conductivity-temperature-depth casts were conducted throughout the sampling period using a Seabird SBE 25 CTD fitted with a SeaTech fluorometer. Nitrate, silicate and phosphate concentrations were determined in an EnviroFlow 3500 nutrient analyser (Perstorp Analytical) from Niskin bottle samples that were filtered through $0.45 \mu \mathrm{m}$ cellulose acetate filters. Nitrate and nitrite were measured together since we have previously found that nitrite concentrations are approximately $1 \%$ of the nitrate + nitrite concentrations in Newfoundland waters (Parrish 1998). Plankton was sampled by towing a $20 \mu \mathrm{m}$ mesh net vertically from $80 \mathrm{~m}$ to the surface. In these waters, this sampling procedure collects diatoms, dinoflagellates

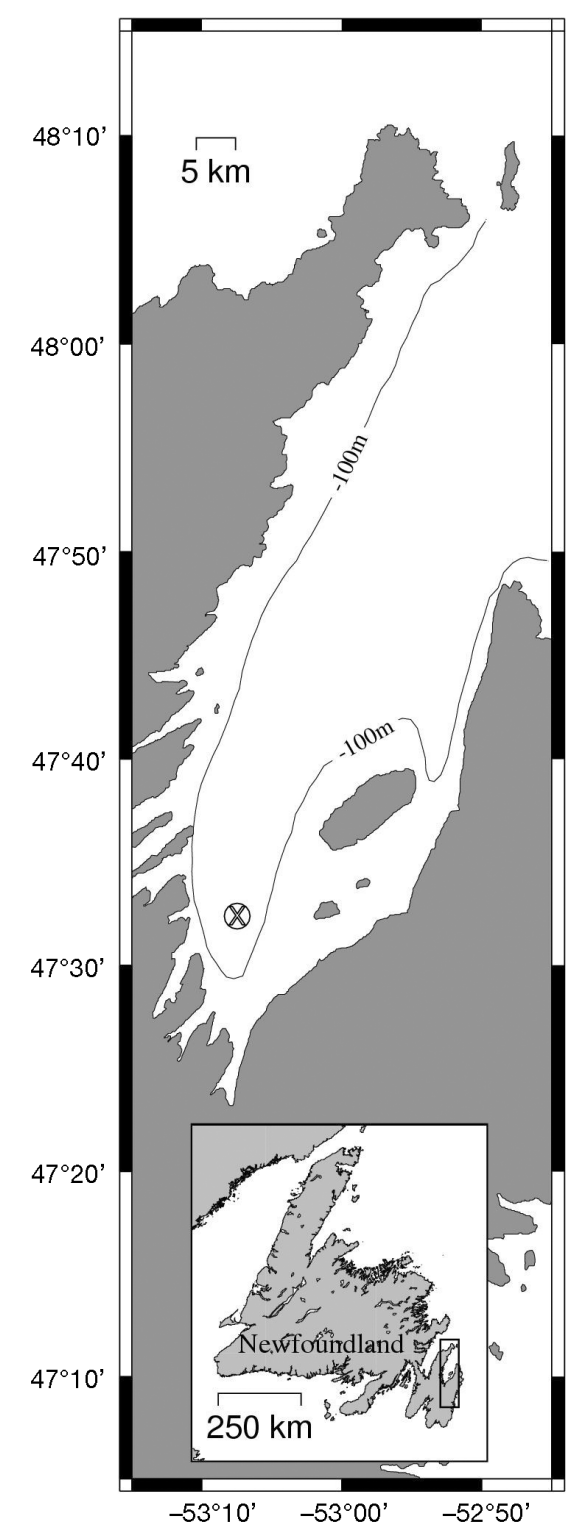

Fig. 1. Station location (X) in Conception Bay on the southeast coast of the island of Newfoundland

and copepod nauplii (Budge \& Parrish 1998). Plankton in the cod end were poured into plastic containers and kept in darkness on ice until subsampling for lipid and weight determination in the laboratory within $5 \mathrm{~h}$.

Sampling settling matter. Samples of settling matter were collected in a manner very similar to that used in a previous study in Trinity Bay (Parrish 1998). On 6 March 1996 a sediment trap mooring was deployed in $248 \mathrm{~m}$ of water in Conception Bay at Stn BRLP5 $\left(47^{\circ} 32.6^{\prime} \mathrm{N} 53^{\circ} 07.9^{\prime} \mathrm{W}\right)$. Each trap consisted of a $60 \mathrm{~cm}$ PVC pipe, sealed at one end and fitted with a spigot placed at about the bottom $1 \mathrm{l}$ mark. Four traps were set at each of 80 and $220 \mathrm{~m}$ with 2 at each depth being 
poisoned with $5 \mathrm{~g} \mathrm{l}^{-1} \mathrm{HgCl}_{2}$ in $40 \mathrm{ppt} \mathrm{NaCl}_{(\mathrm{aq})}$, the other 2 having only 40 ppt $\mathrm{NaCl}$ solution placed in the bottom at the time of deployment. On 27 March 1996, the traps were recovered, samples were taken and the traps were redeployed. Subsamples for lipid, chloropigment, CHN and weight determination were filtered onto pre-combusted Whatman GF/C glassfibre filters. This procedure was then repeated at $\sim 18 \mathrm{~d}$ intervals until 9 July 1996.

Trap performance. In April 1998 an experiment was conducted to evaluate trap accuracy. A mooring was deployed at Stn BRLP5 in $248 \mathrm{~m}$ of water in Conception Bay for $15 \mathrm{~d}$. Four traps were set at each of 50,75 and $100 \mathrm{~m}$ with 2 at each depth being poisoned with $5 \mathrm{~g} \mathrm{l}^{-1}$ $\mathrm{HgCl}_{2}$ in 40 ppt $\mathrm{NaCl}_{(\mathrm{aq})}$, the other 2 having only $40 \mathrm{ppt}$ $\mathrm{NaCl}$ solution placed in the bottom at the time of deployment. On the day of deployment and recovery $5 \mathrm{l}$ Go-Flo bottles were used to collect seawater at the same depths as used for trap deployment. The traps were sampled in the usual manner on recovery except that the entire contents of one $50 \mathrm{~m}$ non-poisoned and one $50 \mathrm{~m}$ poisoned trap were also sampled in $1 \mathrm{l}$ aliquots. In the laboratory all samples were filtered through $47 \mathrm{~mm}$ Whatman GF/C glass-fibre filters to obtain both dissolved and particulate fractions from both within and outside the traps. Observations were made on the size and number of zooplankton 'swimmers' visible on the filters before their removal.

Lipid analyses. Samples were extracted and analysed based on Parrish (1999). Briefly, samples were extracted in chloroform-methanol (2:1) using a modified Folch procedure. Extracts were analysed with the Chromarod-Iatroscan TLC/FID system for lipid classes (Parrish 1987a). Lipid classes were scanned on the rods in 3 steps with different scan lengths for each step: Iatroscan settings of PPS (partial pyrolysis selection) 22 and 11 for the first 2 chromatograms, and a full scan for the last one. To determine individual fatty acids by gas chromatography, samples were derivatized at $85^{\circ} \mathrm{C}$ with $10 \% \mathrm{BF}_{3} / \mathrm{MeOH}$. Water was then added and the upper, organic layer was withdrawn and placed in a $2 \mathrm{ml}$ vial. The sample was concentrated to $0.5-1.0 \mathrm{ml}$ under nitrogen and $1 \mu \mathrm{l}$ was injected into a Varian 3400 gas chromatograph using a Varian 8100 AutoSampler. Fatty acids were identified mainly with the use of a comprehensive standard (Supelco 37 component FAME mix) and by careful reference to Ackman (1986).

Pigment analyses. Pigments were extracted from sediment trap samples in $90 \%$ acetone at $-20^{\circ} \mathrm{C}$. Chloropigments were separated on a $5 \mu \mathrm{m}$ reverse phase column in a Beckman HPLC using 2 methanolbased solvent systems (Redden 1994).

Carbon, nitrogen, dry and ash weight determinations. For organic carbon and nitrogen determination, samples were dried at $60^{\circ} \mathrm{C}$ and combusted in a Perkin-Elmer 240A CHN analyser. Weights were measured on samples that had been washed with 5 to $10 \mathrm{ml}$ of $3 \%$ ammonium formate before drying for 16 to $18 \mathrm{~h}$ at $80^{\circ} \mathrm{C}$. These samples were then combusted at $450^{\circ} \mathrm{C}$ to determine weight loss.

\section{RESULTS AND DISCUSSION}

\section{Hydrographic conditions}

In March 1996, the temperature was below zero throughout the water column at the mooring station in Conception Bay (Fig. 2), and it remained sub-zero below $75 \mathrm{~m}$ until mid-August. Below $180 \mathrm{~m}$, salinity and density were greater than 32.8 and 26.4 respectively throughout the sampling period. Salinity and density data suggest a mixing event down to $\sim 100 \mathrm{~m}$ at the beginning of April. A strong pycnocline developed near the end of June when salinities and densities dropped below 32.0 and 25.0 respectively in the top $15 \mathrm{~m}$ of the water column.
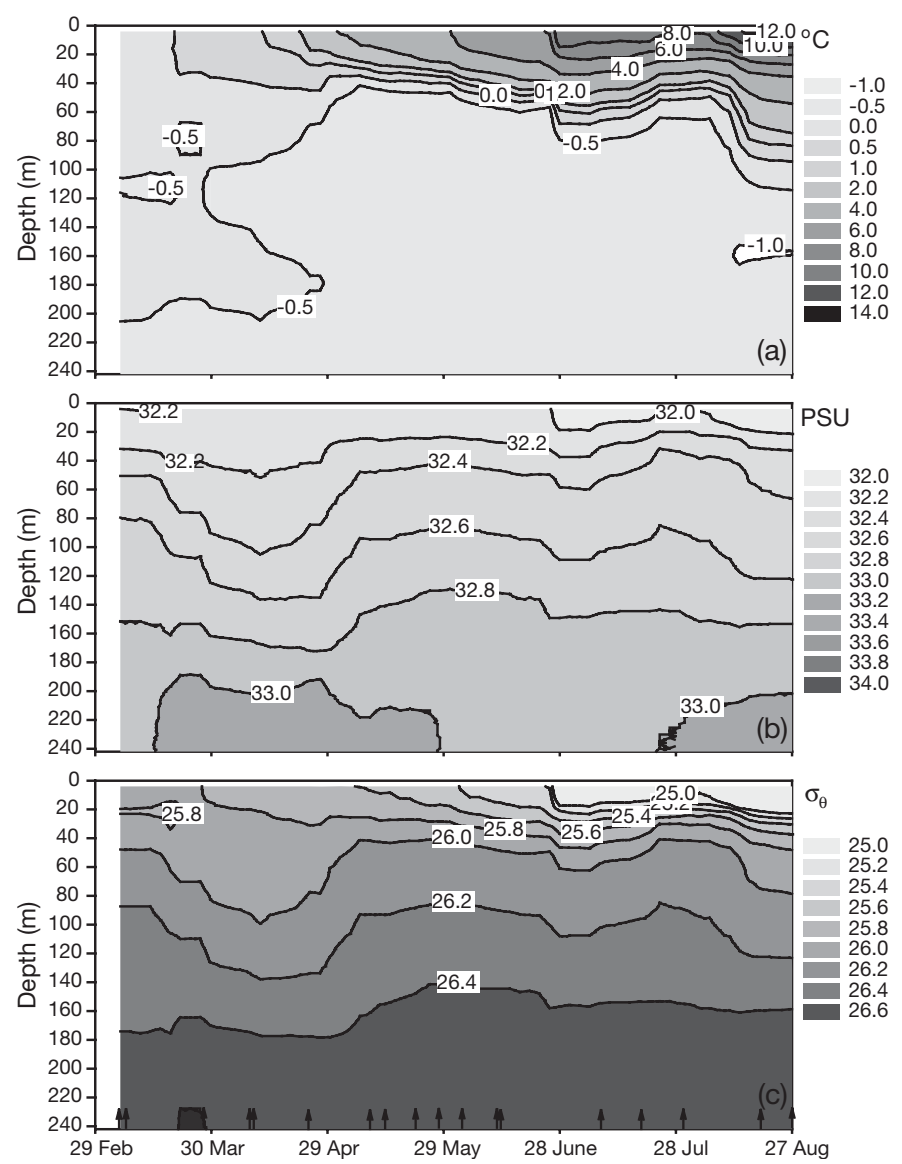

Fig. 2. Temperature $\left({ }^{\circ} \mathrm{C}\right)$, salinity (psu) and density (sigma- $\theta$ ) during the 1996 spring diatom increase in Conception Bay, Newfoundland. Arrows indicate dates of casts 
In situ fluorescence data were used to track the progress of the 1996 spring diatom increase (Fig. 3a). The timing of the start, the maximum and the arrival to the benthos was determined using unsmoothed data and 2 different contouring programs (Surfer ${ }^{\circledR}$ and SigmaPlot ${ }^{\circledR}$ ). The bloom started on 15 March or Julian Day 75 (2.0 contour), the first arrival of bloom material to the benthos was 25 d later (0.5 contour) on 9 April, and the bloom maximum (centre of 6.0 contour) occurred on 24 April, 40 d after the start of the bloom. The depth of the chlorophyll maximum ranged from 15 to $50 \mathrm{~m}$. There was also a small bloom in mid-June on Julian Day 165 (centre of the 2.0 contour).

It is widely accepted that seasonal spring blooms in temperate coastal oceans are terminated by exhaustion of nutrients in the photic zone, which leads to increased sedimentation of phytoplankton cells (Smetacek 1985). Reduced nutrient concentrations in a welldeveloped diatom bloom can cause diatoms to aggregate, sink and leave the photic zone (Andreassen \& Wassmann 1998). In shallow waters, diatoms can reach the sediment surface as intact cells following the spring bloom (Graf 1992).

Silicate and phosphate concentrations decreased by $\sim 50 \%$ between 6 March (10-18 m) and 24 April (10 to $50 \mathrm{~m}$ ) while nitrate decreased to $\sim 10 \%$ of the 6 March values (Fig. 3). The highest nitrate concentrations were

Table 1. Composition of particulate matter during the spring bloom in Conception Bay. Overall average proportions (\%). Data are mean $\pm \mathrm{SD}, \mathrm{n}=6$ to 8 . Sediment trap data are from unpoisoned traps. POM: particulate organic matter (ash free dry weight); TPM: total particulate matter (dry weight); TL: total lipid (sum of Iatroscan determined lipid classes); Neutral lipids: hydrocarbons, wax and steryl esters, ketones, triacylglycerols, free fatty acids; (FFA), alcohols (ALC), sterols, diacylglycerols; Polar lipids: monoacylglycerols, acetone-mobile polar lipids, phospholipids; LI: lipolysis index [(FFA + ALC) (acyl lipids $\left.+\mathrm{ALC})^{-1}\right] ;$ HI: hydrolysis index $[(\mathrm{FFA}+\mathrm{ALC})$ (neutral acyl lipids + ALC) ${ }^{-1}$ ]

\begin{tabular}{|llll|}
\hline & $\begin{array}{c}\text { Tows from } \\
80 \mathrm{~m}\end{array}$ & \multicolumn{1}{c}{$\begin{array}{c}80 \mathrm{~m} \\
\text { traps }\end{array}$} & $\begin{array}{c}220 \mathrm{~m} \\
\text { traps }\end{array}$ \\
\hline POM/TPM & $58.6 \pm 9.49$ & $49.9 \pm 12.77$ & $32.7 \pm 8.12$ \\
TL/TPM & $3.41 \pm 1.67$ & $1.83 \pm 0.93$ & $0.57 \pm 0.25$ \\
TL/POM & $5.75 \pm 2.36$ & $0.39 \pm 0.21$ & $0.20 \pm 0.10$ \\
Neutral/TL & $65.5 \pm 10.32$ & $70.3 \pm 7.97$ & $62.8 \pm 6.91$ \\
Polar/TL & $34.5 \pm 10.32$ & $29.8 \pm 7.97$ & $37.2 \pm 6.91$ \\
LI & $19.4 \pm 6.73$ & $17.6 \pm 6.04$ & $18.1 \pm 5.20$ \\
HI & $31.9 \pm 13.44$ & $26.9 \pm 9.21$ & $30.7 \pm 8.57$ \\
\hline
\end{tabular}

observed that same day at $220 \mathrm{~m}$, together with some of the highest silicate and phosphate concentrations. Such values occurred near the middle of the period of bloom arrival to the benthos, strongly suggesting that remineralization was responsible for the high concentrations. It is noteworthy that this maximum occurred at the same time as the bloom maximum in surface waters (Fig. 3a) and that the N:P molar ratio was 9.3, suggesting regeneration from nitrogen depleted particles.

During the period of trap deployment in April 1998, hydrographic conditions were very similar to those observed in April 1996; however, the 1998 bloom started earlier in March and reached its maximum earlier in April (authors' unpubl. data). Furthermore, the fluorescence maximum was about twice as large in 1998.

\section{Plankton}

Total lipid concentrations in plankton were on average, $3.4 \pm 1.7 \%$ of dry weight (Table 1) and were greater $(p=0.040)$ at the height of the bloom in April, reaching a maximum of $6.3 \pm 2.5 \%$ dry weight (Fig. 4a). There is evidence of another increase in lipids during the small bloom in mid-June on Julian Day 165. In both cases, increases in neutral lipids accounted for most of the increase. Neutral lipids were also slightly elevated at the beginning of the sampling period. The major neutral lipid class in plankton was 

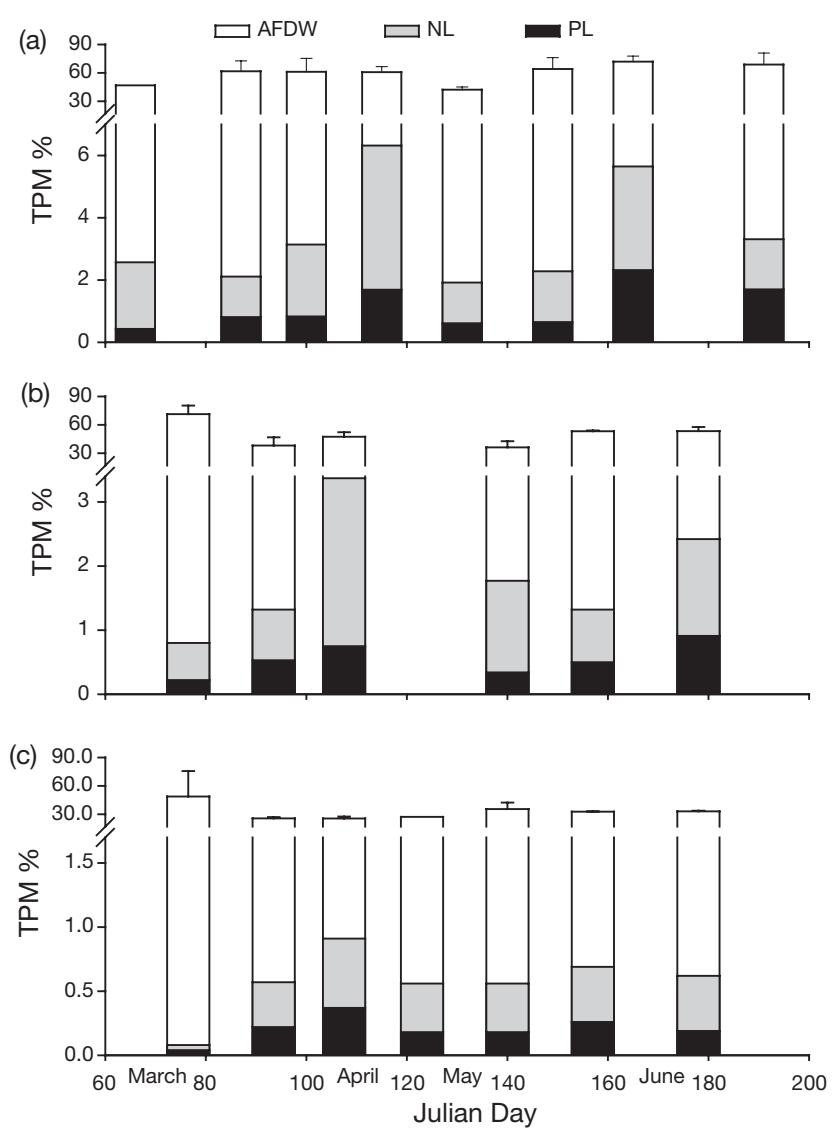

Fig. 4. Ash free dry weight (AFDW) and total lipid content of particulate matter during the spring bloom in Conception Bay, Newfoundland. (a) Vertical plankton tows from $80 \mathrm{~m}$ to the surface. (b) $80 \mathrm{~m}$ sediment trap samples. (c) $220 \mathrm{~m}$ sediment trap samples. The shaded lipid portion is divided into neutral lipid (NL) and polar lipid (PL). Data are mean + SD, $\mathrm{n}=3$ for net-tows and mean $+1 / 2$ range, $\mathrm{n}=2$ for sediment traps. Note factor of 2 in pre-break scalings

Table 2. Lipid composition (\% total lipid) of particulate matter during the spring bloom in Conception Bay. Data are mean \pm $\mathrm{SD}, \mathrm{n}=8$ for plankton and 7 for sediment traps

\begin{tabular}{|lccc|}
\hline & $\begin{array}{c}\text { Tows from } \\
80 \mathrm{~m}\end{array}$ & $\begin{array}{c}80 \mathrm{~m} \\
\text { traps }\end{array}$ & $\begin{array}{c}220 \mathrm{~m} \\
\text { traps }\end{array}$ \\
\hline $\begin{array}{lccc}\text { Hydrocarbons } \\
\text { Steryl/wax esters }\end{array}$ & $1.18 \pm 1.26$ & $1.77 \pm 1.54$ & $1.91 \pm 1.27$ \\
Methyl esters & $1.00 \pm 1.22$ & $1.33 \pm 1.64$ & $1.75 \pm 1.45$ \\
Triacylglycerols & $18.0 \pm 7.42$ & $20.2 \pm 6.97$ & $19.7 \pm 5.35$ \\
Free fatty acids & $14.7 \pm 6.83$ & $13.8 \pm 6.36$ & $12.2 \pm 5.82$ \\
Alcohols & $3.31 \pm 1.59$ & $2.94 \pm 0.75$ & $4.16 \pm 1.00$ \\
Pink pigment & $0.10 \pm 0.29$ & $0.12 \pm 0.20$ & $0.50 \pm 0.66$ \\
$\begin{array}{l}\text { Sterols } \\
\text { Diacylglycerols }\end{array}$ & $4.99 \pm 1.38$ & $5.64 \pm 2.17$ & $6.61 \pm 1.18$ \\
$\begin{array}{l}\text { Acetone mobile } \\
\text { polar lipids }\end{array}$ & $18.1 \pm 7.88$ & $3.88 \pm 1.01$ & $5.77 \pm 1.12$ \\
Phospholipids & $16.4 \pm 9.56$ & $15.2 \pm 6.40$ & $16.2 \pm 3.51$ \\
\hline
\end{tabular}

triacylglycerol (Table 2). In diatoms and dinoflagellates high triacylglycerol production is usually associated with lower growth rates (Sicko-Goad \& Andresen 1991, Parrish et al. 1994), as is often found at the beginning and especially the end of batch culture experiments. Seawater concentrations of particulate triacylglycerol were also slightly elevated near the beginning of a bloom in Bedford Basin, Nova Scotia, and then at their maximum from the time of the chlorophyll maximum onwards (Parrish 1987b).

Proportions of polyunsaturated fatty acids (PUFA) were high from the beginning of the bloom until the end of May (44 to 53\%: Fig. 5a). These values are similar to the 31 to $54 \%$ observed in net-tows from adjacent Trinity Bay in March-June 1996 (Budge \& Parrish 1998), and are about as high as the highest (55\%) observed in coastal and fjord plankton in Antarctica
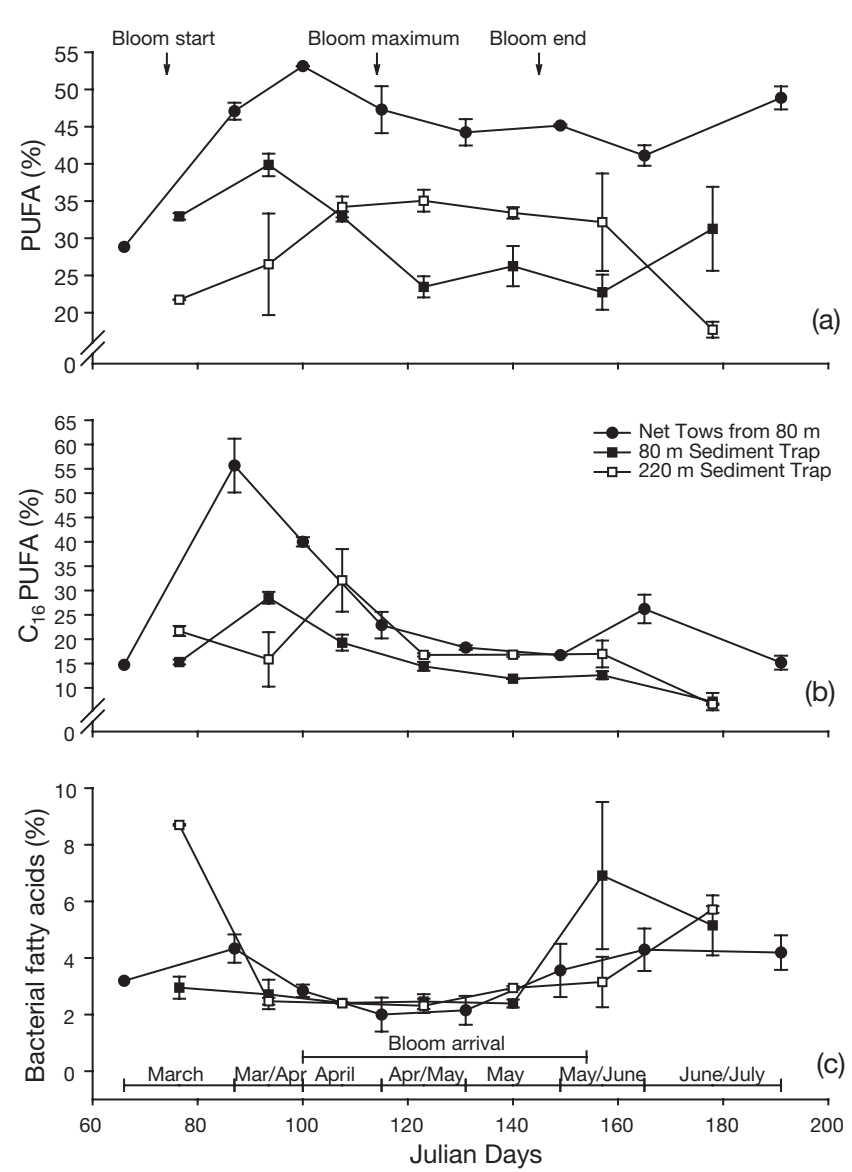

Fig. 5. Fatty acid proportions (\%) in plankton and settling particulate matter during the spring bloom in Conception Bay, Newfoundland. (a) Polyunsaturated fatty acids as a proportion of total fatty acids. (b) $\mathrm{C}_{16}$ PUFA ratio (see text for definition). (c) Bacterial fatty acids $(i 15: 0+$ ai15:0 + 15:0 + i16:0 + ai16:0 + $i 17: 0+a i 17: 0+17: 0$ ) as a proportion of total fatty acids. The periods of trap deployments and bloom arrival to the benthos are indicated at the bottom. Data are mean $\pm \mathrm{SD}, \mathrm{n}=3$ for net-tows and mean $\pm 1 / 2$ range, $n=2$ for sediment traps 
(Skerratt et al. 1995). There was, however, a decrease in PUFA proportions between April and June in Conception Bay during the period of low nutrient concen-

Table 3. Fatty acid composition (\% total fatty acids) during the spring bloom in Conception Bay. Data are overall means, $\mathrm{n}=7$ to 8 ; trap data are for unpoisoned traps only

\begin{tabular}{|c|c|c|c|c|c|c|}
\hline & \multicolumn{2}{|c|}{ Plankton } & \multicolumn{2}{|c|}{$80 \mathrm{~m}$ trap } & \multicolumn{2}{|c|}{$220 \mathrm{~m}$ trap } \\
\hline & Mean & $\mathrm{SD}$ & Mean & $\mathrm{SD}$ & Mean & $\mathrm{SD}$ \\
\hline $14: 0$ & 9.74 & 1.69 & 8.04 & 2.74 & 7.28 & 2.06 \\
\hline i15:0 & 0.38 & 0.29 & 9.00 & 4.51 & 9.43 & 4.27 \\
\hline ai15:0 & 0.44 & 0.24 & 6.12 & 2.43 & 6.43 & 2.85 \\
\hline $15: 0$ & 0.55 & 0.17 & 0.68 & 0.20 & 0.78 & 0.44 \\
\hline i16:0 & 0.21 & 0.11 & 0.28 & 0.24 & 0.32 & 0.23 \\
\hline ai16:0 & 0.11 & 0.09 & 0.24 & 0.29 & 0.16 & 0.12 \\
\hline $16: 0$ & 12.19 & 2.79 & 15.00 & 2.68 & 12.75 & 2.01 \\
\hline $16: 1 \omega 7$ & 12.86 & 4.05 & 18.43 & 5.50 & 22.12 & 4.12 \\
\hline $16: 1 \omega 5$ & 0.53 & 0.41 & 0.26 & 0.26 & 0.44 & 0.40 \\
\hline$i 17: 0$ & 1.18 & 0.76 & 0.64 & 0.23 & 0.77 & 0.47 \\
\hline ai17:0 & 0.27 & 0.26 & 0.25 & 0.13 & 0.20 & 0.10 \\
\hline $16: 2 \omega 4$ & 1.79 & 0.66 & 1.44 & 0.46 & 1.56 & 0.43 \\
\hline $17: 0$ & 0.17 & 0.14 & 0.21 & 0.12 & 0.25 & 0.23 \\
\hline $16: 3 \omega 4$ & 1.86 & 1.36 & 1.58 & 1.23 & 1.66 & 0.77 \\
\hline $16: 4 \omega 3$ & 0.76 & 0.56 & 0.37 & 0.14 & 0.64 & 0.47 \\
\hline $16: 4 \omega 1$ & 5.97 & 6.65 & 3.26 & 2.41 & 4.38 & 2.71 \\
\hline $18: 0$ & 1.05 & 0.45 & 1.17 & 0.54 & 1.29 & 0.62 \\
\hline $18: 1 \omega 9$ & 4.22 & 3.85 & 4.94 & 3.13 & 4.56 & 1.61 \\
\hline $18: 1 \omega 7$ & 1.47 & 0.82 & 2.65 & 1.10 & 1.91 & 0.92 \\
\hline $18: 1 \omega 6 ?$ & 0.02 & 0.05 & 0.00 & 0.00 & 0.00 & 0.00 \\
\hline $18: 1 \omega 5$ & 0.62 & 0.41 & 0.72 & 0.26 & 0.41 & 0.37 \\
\hline $18: 2 \omega 6$ & 1.02 & 0.40 & 1.00 & 0.42 & 0.90 & 0.35 \\
\hline $18: 2 \omega 4$ & 0.14 & 0.12 & 0.30 & 0.15 & 0.12 & 0.07 \\
\hline $18: 3 \omega 6$ & 0.16 & 0.10 & 0.08 & 0.04 & 0.06 & 0.06 \\
\hline $18: 3 \omega 4$ & 0.07 & 0.17 & 0.01 & 0.04 & 0.01 & 0.02 \\
\hline $18: 3 \omega 3$ & 0.39 & 0.26 & 0.25 & 0.15 & 0.32 & 0.15 \\
\hline $18: 4 \omega 3$ & 2.92 & 1.39 & 2.10 & 1.34 & 2.06 & 1.30 \\
\hline $18: 4 \omega 1$ & 0.11 & 0.14 & 0.03 & 0.04 & 0.01 & 0.02 \\
\hline $20: 0$ & 0.01 & 0.03 & 0.02 & 0.03 & 0.04 & 0.06 \\
\hline $18: 5 \omega 3$ & 0.00 & 0.00 & 0.09 & 0.17 & 0.01 & 0.03 \\
\hline $20: 1 \omega 9(11)$ & 1.36 & 1.44 & 1.79 & 1.10 & 1.29 & 0.92 \\
\hline $20: 1 \omega 7$ & 0.24 & 0.12 & 0.44 & 0.31 & 0.28 & 0.17 \\
\hline $20: 2 \omega 6$ & 0.12 & 0.10 & 0.12 & 0.12 & 0.29 & 0.21 \\
\hline $20: 3 \omega 6$ & 0.00 & 0.00 & 0.00 & 0.02 & 0.18 & 0.31 \\
\hline $20: 4 \omega 6$ & 0.32 & 0.28 & 2.51 & 2.24 & 0.70 & 0.80 \\
\hline $20: 3 \omega 3$ & 0.09 & 0.23 & 0.06 & 0.05 & 0.03 & 0.04 \\
\hline $20: 4 \omega 3$ & 0.68 & 0.44 & 0.40 & 0.21 & 0.21 & 0.09 \\
\hline $20: 5 \omega 3$ & 17.86 & 6.71 & 10.90 & 2.50 & 12.66 & 6.47 \\
\hline $22: 0$ & 0.01 & 0.04 & 0.01 & 0.02 & 0.01 & 0.02 \\
\hline $22: 1 \omega 11(13)$ & 0.82 & 1.35 & 1.00 & 0.65 & 0.78 & 0.72 \\
\hline $22: 1 \omega 9$ & 0.14 & 0.20 & 0.53 & 0.21 & 0.32 & 0.23 \\
\hline $22: 1 \omega 7$ & 0.00 & 0.00 & 0.07 & 0.13 & 0.01 & 0.02 \\
\hline $21: 5 \omega 3$ & 0.22 & 0.13 & 0.17 & 0.06 & 0.14 & 0.13 \\
\hline $23: 0$ & 0.02 & 0.04 & 0.03 & 0.05 & 0.02 & 0.06 \\
\hline $22: 4 \omega 6$ & 0.04 & 0.09 & 0.04 & 0.07 & 0.03 & 0.06 \\
\hline $22: 4 \omega 3$ & 0.16 & 0.30 & 0.04 & 0.06 & 0.03 & 0.04 \\
\hline $22: 5 \omega 6$ & 0.14 & 0.17 & 0.10 & 0.10 & 0.04 & 0.04 \\
\hline $22: 5 \omega 3$ & 0.56 & 0.47 & 0.36 & 0.16 & 0.16 & 0.10 \\
\hline $24: 0^{\mathrm{a}}$ & 0.00 & 0.00 & 0.00 & 0.00 & 0.00 & 0.00 \\
\hline $22: 6 \omega 3$ & 9.09 & 5.26 & 4.72 & 3.04 & 2.48 & 0.96 \\
\hline $24: 1$ & 0.05 & 0.08 & 0.11 & 0.14 & 0.19 & 0.19 \\
\hline
\end{tabular}

trations in surface waters. Nitrate (Sukenik \& Wahnon 1991), phosphate (Harrison et al. 1990, Reitan et al. 1994) and silica limitation (Harrison et al. 1990) decrease $\omega 3$ PUFA proportions in microalgae. However, the ratio of $22: 6 \omega 3$ to $20: 5 \omega 3$, the 2 largest contributors (Table 3), increased from May onwards indicating a greater relative contribution of dinoflagellate lipids (Ramos et al. 2003).

Shin et al. (2000) proposed a 'Polyunsaturation Index of $\mathrm{C}_{16}$ fatty acids' as an indicator of the physiological status of diatoms. They used the ratio $(16: 2 \omega 7$ $+16: 3 \omega 4+16: 4 \omega 1$ to $16: 0+16: 1 \omega 9+16: 1 \omega 7+16: 1 \omega 5+$ $16: 2 \omega 7+16: 3 \omega 4+16: 4 \omega 1)$ to show the effects of nitrate limitation. We used a slight modification of both the calculation and the name (Fig. 5b). Our $\mathrm{C}_{16}$ PUFA ratio is defined as the ratio $(16: 2 \omega 4+16: 3 \omega 4+16: 4 \omega 3+$ $16: 4 \omega 1$ to $16: 0+16: 1 \omega 7+16: 1 \omega 5+16: 2 \omega 4+16: 3 \omega 4+$

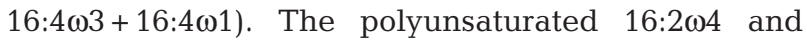

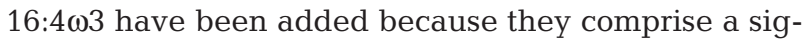
nificant portion $(>2 \%$ ) of the total fatty acids in some species of diatom (Viso \& Marty 1993, Dunstan et al. 1994) and were present at about this level in our samples (Table 3). The $\mathrm{C}_{16}$ PUFA ratio was highest in the net tow sample taken immediately after the start of the bloom. This value of $56 \%$ was much higher than the highest Polyunsaturation Index of $\mathrm{C}_{16}$ fatty acids (33\%) measured by Shin et al. (2000) in Japanese waters. The $\mathrm{C}_{16}$ PUFA ratio maximum preceded the overall PUFA maximum by $13 \mathrm{~d}$ and declined rapidly as nitrate concentrations fell (Figs. 3b \& 5b).

Bacterial fatty acid markers in the plankton were at their lowest throughout April and into the middle of May (2.0 to $2.8 \%$ of total fatty acids: Fig. 5c). Antarctic phytoplankton have shown antibacterial activity (Sieburth 1959), so low contributions by bacteria to the fatty acid pool could indicate allelopathy between plants and bacteria during the bloom period. In a mesocosm experiment in warmer water, bacterial i15:0 concentrations were low during a diatom bloom (Hayakawa et al. 1996); however, in Conception Bay comparatively low contributions more likely result from the use of proportions. The lowest proportion $(2.00 \pm$ $0.60 \%$ ) occurred on 24 April when total lipid concentrations were at their highest (Fig. 4a). The highest proportion $(4.33 \pm 0.50 \%)$ occurred on 27 March when total lipid concentrations were at their second lowest, one third of the highest value.

\section{Changes in the nature of particles during transfer to the benthos}

Overall, organic matter and total lipid concentrations decreased continuously in the transition from plankton to near bottom particles (Table 1), so that deep trap 
values were significantly lower $(p<0.05)$. This was not the case for the components of the total lipids, although there were differences in neutral and polar lipid proportions between the 2 trap depths $(p=0.049)$. Differences in neutral lipid proportions suggest catabolism of storage lipids or increases in membrane lipids in deep sediment traps. On the other hand, the average lipolysis index remained the same at 18 to $19 \%$ in all samples (Table 1). There was no increase with depth probably because the bloom maximum occurred around $50 \mathrm{~m}$ at sub-zero temperatures and the traps were deployed in sub-zero waters throughout. The closely related hydrolysis index ( $\mathrm{HI}_{i}$ Weeks et al. 1993) was also not different among the samples and not different to the previous study in Trinity Bay (Parrish 1998) where net tow and trap samples were taken from the top $100 \mathrm{~m}$ of the water column. The median HI value of 31 for Conception Bay, with a range of 12 to 49 , is indicative of low bloom utilization in surface waters (Weeks et al. 1993)

There were no trends with depth in the distributions of any of the major lipid classes nor in some of the minor classes as the organic material sank from the photic zone through the water column (Table 2). However, hydrocarbons, methyl esters, a pink pigment and sterols did increase continuously between net-tow and $220 \mathrm{~m}$ trap samples, and free fatty acids surprisingly decreased continuously. The pink pigment has been tentatively identified as a peridinin-like pigment (Parrish 1998). Lipid classes showing no continuous trends in relative proportions with depth were the energy storage triacylglycerols, the breakdown indicator alcohols (Weeks et al. 1993) and diacylglycerols, and the membrane phospholipids. Wax esters in the combined wax ester/steryl ester Iatroscan peak are zooplankton energy stores, and the acetone-mobile polar lipid peak contains the monoacylglycerol breakdown indicator and the membrane glycolipids.

As a proportion of dry weight, all but one of the lipid classes decreased continuously in the transition from plankton to the $220 \mathrm{~m}$ trap, consistent with the large decrease in total lipid as a proportion of dry weight (Table 1). The only exception was, again, a minor component of the extract, the peridinin-like pigment. This characteristic pigment of the dinoflagellates (Goodwin 1974) was present in its highest proportion in the $220 \mathrm{~m}$ trap.

Although most lipid classes decreased as a proportion of dry weight during transfer to the benthos, the range in values for each lipid class between the tow data and the $220 \mathrm{~m}$ trap data was actually lower than was found among the 8 tow means. This, combined with the almost total lack of significant differences in lipid class proportions (Table 2), suggests that changes in lipids as a proportion of dry weight (Table 1) are due, in part, to admixture of lipid-poor material.
Eicosapentaenoic acid (20:5 $\omega 3$ ) was, on average, the major fatty acid in the net-tow samples while 16:1 107 was the major fatty acid in sediment trap samples (Table 3). Nine PUFA (18:2 $\omega 6,18: 4 \omega 3,18: 4 \omega 1,20: 4 \omega 3$, $21: 5 \omega 3,22: 4 \omega 3,22: 5 \omega 6,22: 5 \omega 3,22: 6 \omega 3)$ showed a continuous relative decrease with depth, while 7 saturates (i15:0, ai15:0, 15:0, i16:0, 17:0, 18:0, 20:0) and 2 monoenes $(16: 1 \omega 7,24: 1)$ showed an increase. Such opposing trends suggest replacement of diatom fatty acids by bacterial ones. The PUFA 18:2 $\omega 6,18: 4 \omega 3,18: 4 \omega 1$,

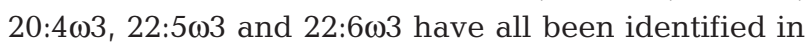
a pennate diatom isolated from Canadian waters (Parrish et al. 1991), while the iso (i) and anteiso (ai) branched chain saturated fatty acids are major constituents in Gram-positive bacteria (Fulco 1983). However, the replacement is apparently selective since the pennate diatom had 16:1 $1 \omega 7$ as its major fatty acid, as is commonly found in diatoms (Volkman et al. 1989, Viso \& Marty 1993), and this monoene showed the opposite trend (Table 3). This indicates PUFA may be selectively removed, catabolized or chemically oxidised during passage through the water column, although degradation rates are likely to be slow in cold water

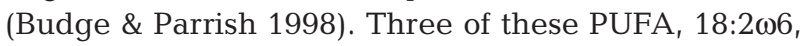

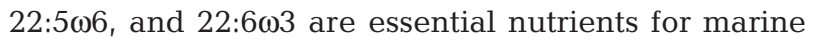
invertebrates (Xu et al. 1994, Pond et al. 1996, Milke et al. 2004).

Notwithstanding apparent trends in the nature of the fatty acid composition of particles during transfer to the benthos, it is important to note that the ranges between the plankton and $200 \mathrm{~m}$ trap means were, in fact, almost always smaller than found in plankton and trap material over the season. The ranges for PUFA showing trends in Table 3 were always smaller than those found in the 8 net tows, while the ranges in the saturates and monoenes showing upward trends were always smaller than in the $80 \mathrm{~m}$ and $220 \mathrm{~m}$ trap data. Thus, for these fatty acids, temporal variability was greater than depth variability on average, suggesting that changes in the nature of the lipids during transfer to the benthos were comparatively small. Indeed, cluster analysis has revealed that the fatty acid composition of yellowtail flounder Limanda ferruginea in Conception Bay is quite similar to that of plankton and settling particulate matter (Dwyer et al. 2003).

The major fatty acids (means $>1 \%$ in all samples) showing no trends with depth were 16:0, 16:2 $\omega 4$,

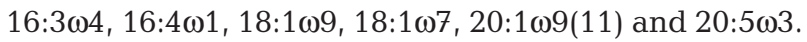
This last long-chain PUFA is an essential fatty acid which has been shown to be important in maintaining fluidity in the membrane of a cold water bivalve (Hall et al. 2002). The saturated fatty acid 16:0 is common to all life forms, while the $\mathrm{C}_{16}$ polyenes were major fatty acids in the pennate diatom from Atlantic Canada (Parrish et al. 1991). The $\mathrm{C}_{18}$ monoenes have been used to 
indicate feeding behaviour in cold water benthos (Graeve et al. 1997), and the monoene 20:1 09 (in the combined 20:1 $\omega 9+20: 1 \omega 11$ GC peak) is prominent in cold water herbivorous copepods (Albers et al. 1996).

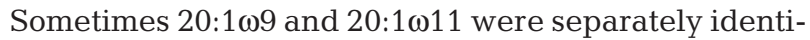
fiable with an average $\omega 9 / \omega 11$ ratio of $\sim 2$ in net-tow lipids and 10 in sediment trap lipids. Likewise, on 2 occasions the other long-chain monoenes 22:1011 and 22:1 $\omega 13$ were separately identifiable in sediment trap lipids with $\omega 11 / \omega 13$ ratios of 3 and 5 . Among the minor fatty acids 3 multiple branched fatty acids were tentatively identified in some samples at proportions between 0.1 and $0.8 \%$ each in net-tows and between 0.1 and $1.1 \%$ each in sediment traps. These were 4,8,12-trimethyltetradecanoic acid and pristanic and phytanic acids, all believed to be derived from the phytol side-chain of chlorophyll (Ackman et al. 1966, Ackman 1986).

\section{Fluxes of particulate matter}

The maximum fluxes of chlorophyll $a_{1}$, phaeopigments, carbon and nitrogen occurred at $80 \mathrm{~m}$ during the April deployment/recovery (Fig. 6) and were similar to maxima determined in the Laurentian Trough (Colombo et al. 1996), but higher than in coastal Antarctica (Hayakawa et al. 1997). Comparisons of areas under the flux curves are given in Table 4 . The data
Table 4. Areas under flux curves and their ratios $(220 \mathrm{~m} / 80 \mathrm{~m})$

\begin{tabular}{|c|c|c|c|}
\hline & $\begin{array}{c}80 \mathrm{~m} \text { traps } \\
\left(\mathrm{g} \mathrm{m}^{-2}\right)\end{array}$ & $\begin{array}{c}220 \mathrm{~m} \text { traps } \\
\left(\mathrm{g} \mathrm{m}^{-2}\right)\end{array}$ & $\begin{array}{c}\text { Ratio } \\
(\%)\end{array}$ \\
\hline TPM & 90.4 & 309 & 342 \\
\hline POM & 42.8 & 91.9 & 215 \\
\hline Chlorophyll a & 0.130 & 0.087 & 66.8 \\
\hline Phaeopigments & 0.184 & 0.194 & 106 \\
\hline Carbon & 22.8 & 20.6 & 90.1 \\
\hline Nitrogen & 5.92 & 4.66 & 78.8 \\
\hline Total lipids & 3.32 & 1.75 & 52.8 \\
\hline Neutral lipids & 2.45 & 1.11 & 45.5 \\
\hline Polar lipids & 0.867 & 0.660 & 76.1 \\
\hline PUFA & 0.629 & 0.345 & 54.8 \\
\hline
\end{tabular}

suggest that most of these 4 organic classes pass though the water column, although the data for dry and ash free dry weight indicate that the fluxes should be compared cautiously. In the case of these TPM and POM data, most of the fluxes at $220 \mathrm{~m}$ were higher than those at $80 \mathrm{~m}$, suggesting additional sources for the $220 \mathrm{~m}$ trap, most likely from resuspension.

The major peak in the HPLC chloropigment chromatograms of trap samples was almost always chlorophyll $a$, although there were always considerable amounts of several phaeopigments, so that their total flux was usually higher than that of chlorophyll $a$. Nonetheless, at the height of the bloom there was no significant difference between the chlorophyll a flux
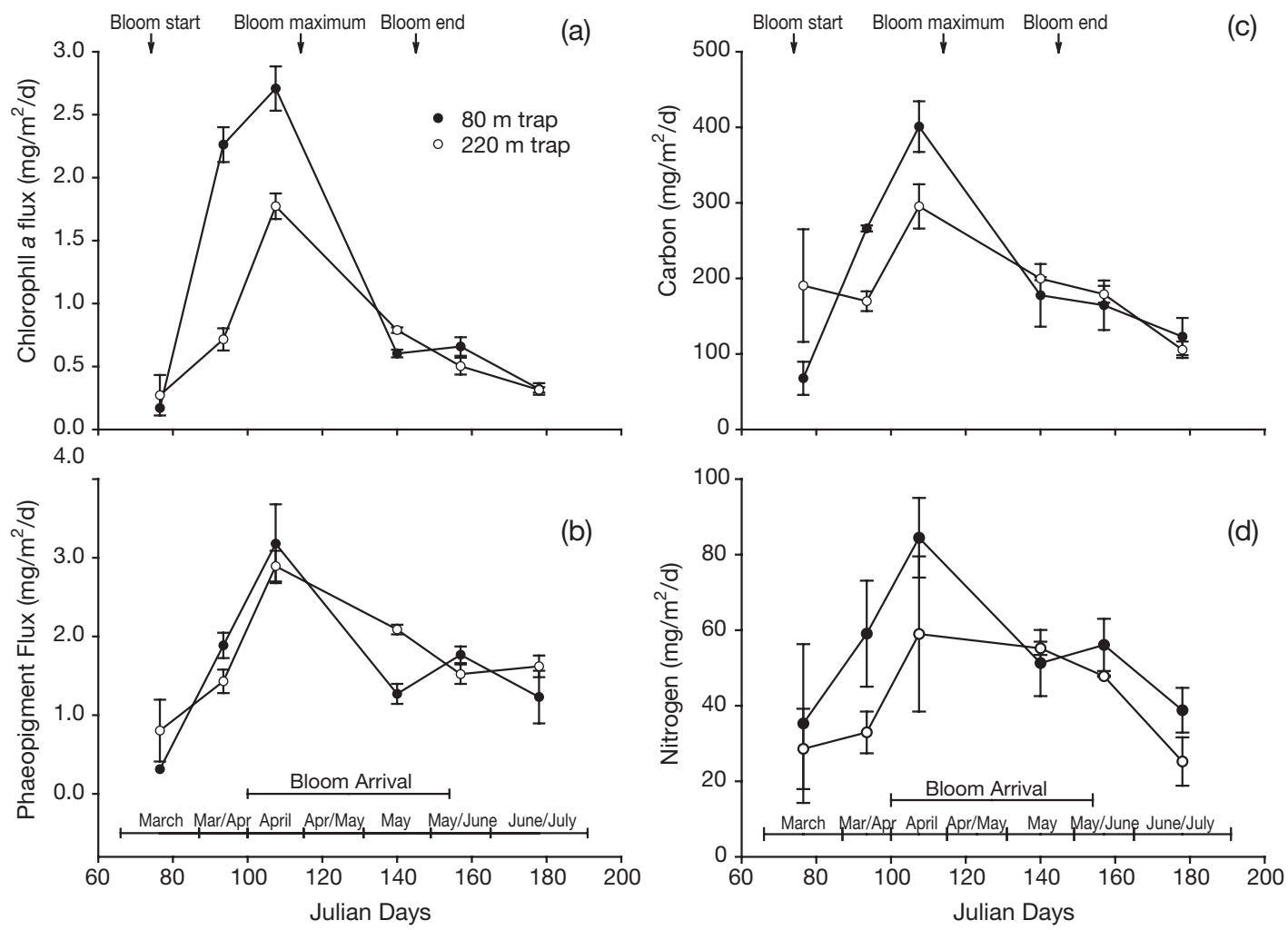

Fig. 6. Fluxes of organic matter during the spring bloom in Conception Bay, Newfoundland. The periods of trap deployments and bloom arrival to the benthos are indicated at the bottom. Data are mean $\pm 1 / 2$ range, $\mathrm{n}=2$ 

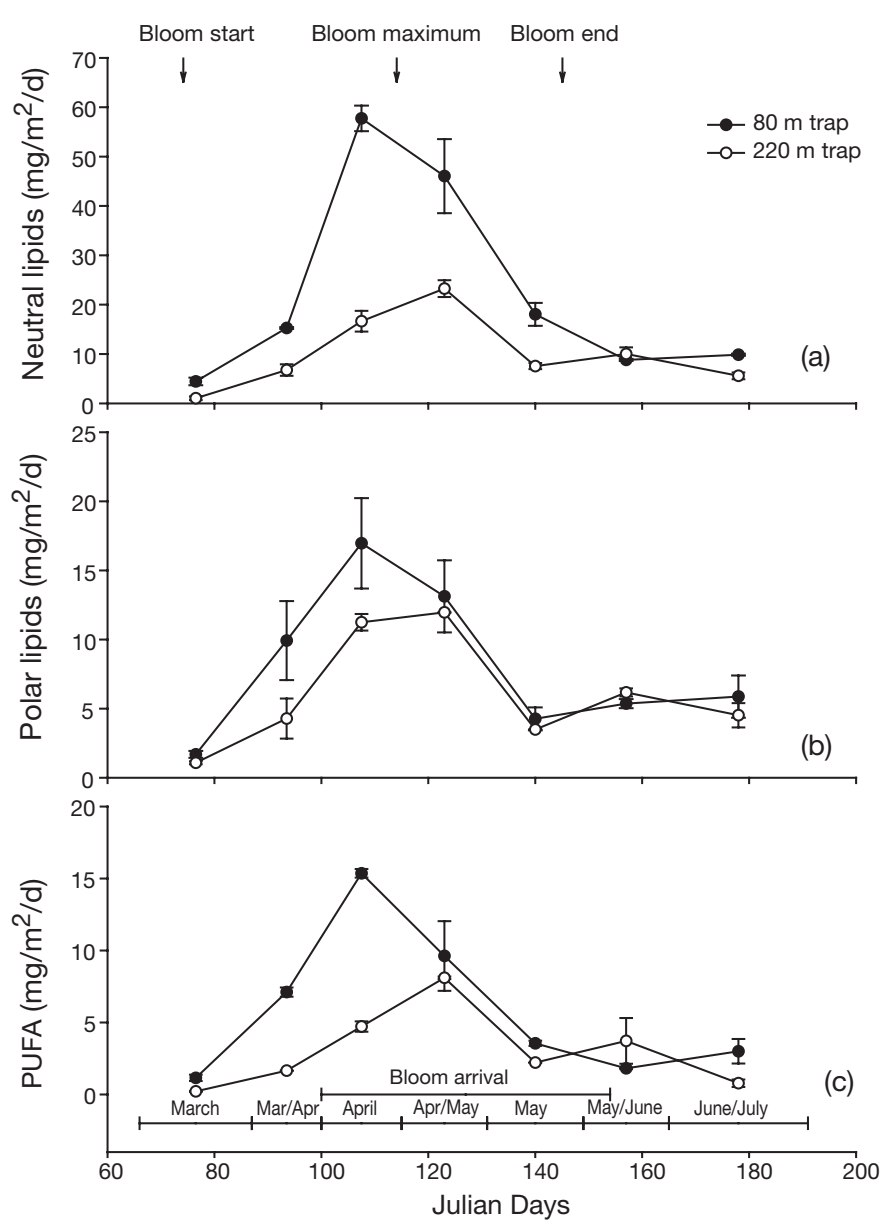

Fig. 7. Neutral lipid, polar lipid and polyunsaturated fatty acid fluxes during the spring bloom in Conception Bay, Newfoundland. The periods of trap deployments and bloom arrival to the benthos are indicated. Data are mean $\pm \frac{1}{2}$ range, $n=2$

and the phaeopigment flux at $80 \mathrm{~m}$ (Fig. 6a,b). Over the bloom period, $67 \%$ of the undegraded chlorophyll a passing through $80 \mathrm{~m}$ reached $220 \mathrm{~m}$ (Table 4) presumably in intact phytoplankton cells and chains. The proportion was higher for phaeopigments, suggesting transport in fast sinking faecal pellets or additional chlorophyll breakdown in transit.

The maximum fluxes of neutral and polar lipids (58 \pm 2.6 and $17 \pm 3.3 \mathrm{mg} \mathrm{m}^{-2} \mathrm{~d}^{-1}$ ) in non-poisoned $80 \mathrm{~m}$ traps occurred at the bloom maximum, while those at $220 \mathrm{~m}$ $\left(23 \pm 1.7\right.$ and $\left.12.0 \pm 0.02 \mathrm{mg} \mathrm{m}^{-2} \mathrm{~d}^{-1}\right)$ occurred $16 \mathrm{~d}$ later (Fig. 7). This gives an apparent settling velocity of $8.8 \mathrm{~m} \mathrm{~d}^{-1}$ for lipid-containing particles. This is considerably slower than the values of 20 to $23 \mathrm{~m} \mathrm{~d}^{-1}$ given by Redden (1994) for Conception Bay, calculated on the basis of carbon measurements. This difference may relate to slower settling rates of lipid rich particles, but it is also related to deployment of the traps. Redden deployed traps for shorter periods and at more depths than was possible here.
Integration of the lipid flux data provides the quantities of lipids in settling particulate matter passing though each depth during the spring bloom (Table 4), which in turn can be compared with lipid accumulation in important benthic species in Conception Bay (Richoux et al. 2004a,b). The maximum net accumulation for populations of the amphipod Acanthostepheia malmgrenii or the mysid Mysis mixta accounts for $~ 4 \%$ each of the $1.75 \mathrm{~g} \mathrm{~m}^{-2}$ total lipid in the $220 \mathrm{~m}$ traps during the 1996 spring bloom. A. malmgrenii and M. mixta are among the 5 most abundant large species in the suprabenthos in Conception Bay (authors' unpubl. data).

PUFA levels in traps ranged from 18 to $40 \%$ of total fatty acids (Fig. 5a), bracketing the year round mean of $20 \%$ in Trinity Bay (Budge \& Parrish 1998), but remaining higher than the maximum $(16.7 \%)$ in coastal Antarctica (Hayakawa et al. 1997). In the deep traps, PUFA were maintained at high levels (33 to 35\%) throughout the period of bloom arrival while bacterial markers were at their lowest (2.3 to $2.9 \%)$. The mean chain length and number of double bonds in fatty acids in the settling particles was the same at the 2 trap depths ( $p$ > 0.25). Again, the values bracketed those from Trinity Bay (Parrish et al. 2002) and averaged 17 carbon atoms and 2 double bonds. These data, combined with low C/N mass ratios (mean of 5.1) at $220 \mathrm{~m}$, indicate a rapid transfer of highly nutritious material to the benthos during the spring bloom in Conception Bay. In order to quantify the transfer, PUFA proportions (Fig. 5a) and lipid class flux data (Fig. 7a,b) can be combined (Budge \& Parrish 2003) to calculate PUFA fluxes (Fig. 7c) and proportions transferred (Table 4). In this way it can be determined that over half the PUFA settling from surface waters reached the benthos. The maximum net PUFA accumulation for populations of Acanthostepheia malmgrenii and Mysis mixta (Richoux 2004) accounts for $\sim 2$ and $4 \%$ respectively of the $0.345 \mathrm{~g} \mathrm{~m}^{-2}$ in the $220 \mathrm{~m}$ traps. The higher value for $M$. mixta suggests that this mysid population was better able to sequester settling PUFA.

\section{Trap performance}

The temperature at the depths of the traps was $-1{ }^{\circ} \mathrm{C}$ on deployment and recovery in 1998. A salinity determination on the bottom litre of the non-poisoned $50 \mathrm{~m}$ trap sample showed it remained within $93 \%$ of its original salinity. This value matched the $95 \%$ value we determined for the efficiency of our on-board particle collection procedure for sediment traps. By sampling the particles in the entire collection tube of both poisoned and non-poisoned traps we could compare the particulate lipid concentrations in the bottom with the rest of each 


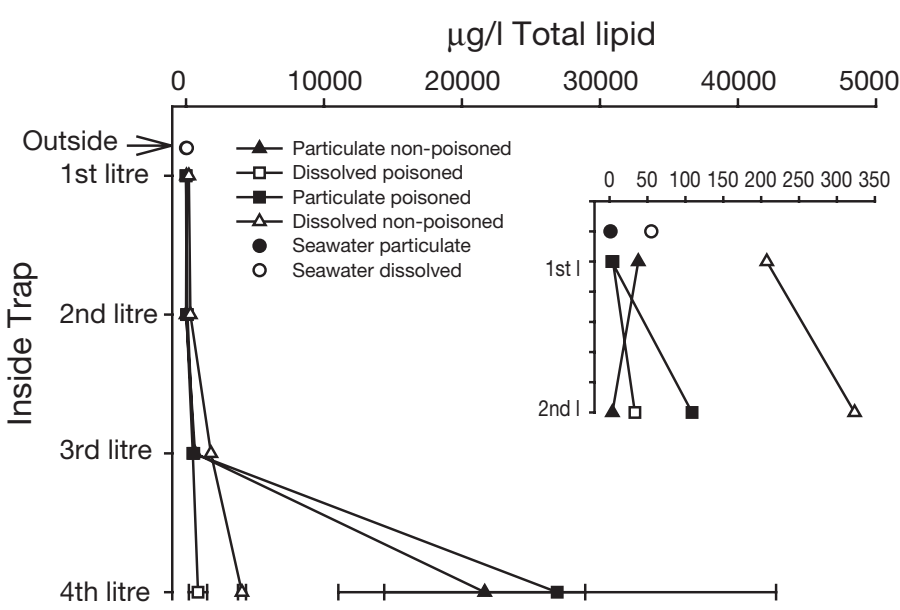

Fig. 8. Dissolved and particulate lipid concentrations within entire sediment traps set at $50 \mathrm{~m}$ for $15 \mathrm{~d}$ in April 1998. Filled symbols represent particulate samples; open symbols represent dissolved samples. Non-poisoned samples are represented by triangles, poisoned samples by squares. Samples taken outside the trap on the day of recovery are represented

by circles. Data for the bottom litre are mean $\pm \frac{1}{2}$ range

trap (Fig. 8). Almost all the particulate lipids in the collection tube were found in the bottom litre, the part of the tube that we would normally sample.

At the top of the trap, both dissolved and particulate lipid concentrations were similar to those found outside the trap, except for dissolved total lipids in the non-poisoned trap, which appear to be greater (Fig. 8, inset). At the bottom of the trap these concentrations are clearly greater and a statistical analysis of the entire sediment trap array revealed that concentrations of dissolved lipids were indeed significantly higher $(\mathrm{p}=0.018)$ in non-poisoned than in poisoned trap bottom layers. By considering the sum of the dis-

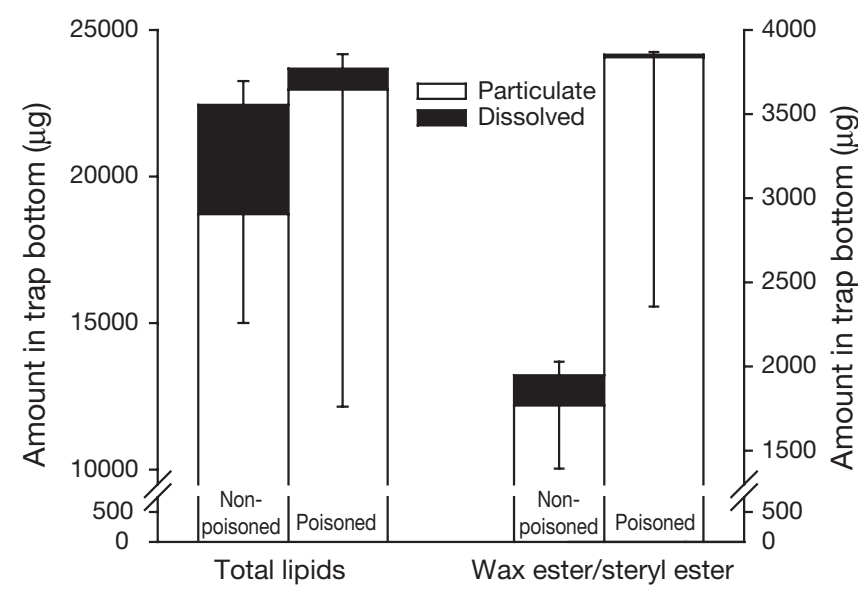

Fig. 9. Dissolved and particulate lipid content in the bottom of $50 \mathrm{~m}$ sediment traps following a $15 \mathrm{~d}$ deployment in April 1998. Total lipid and wax/steryl ester data are mean $+1 / 2$ range for dissolved lipids and mean $-1 / 2$ range for particulate lipids solved and particulate lipids in the trap bottom (Fig. 9) it can be seen that particulate lipids represent a smaller proportion of the total in the non-poisoned traps. For the entire sediment trap array, particulate lipids accounted for $86 \pm 7 \%$ of the total in nonpoisoned traps, which was significantly less $(p=0.016)$ than the $95 \pm 4 \%$ of the total in poisoned traps. The evidence that poisoning is important in the reduction of bacterially mediated dissolution during long-term deployments is supported by the fact that proportions of bacterial fatty acid markers in filtrates were 7 times higher in the bottom layer of non-poisoned traps. However, as expected for low solubility compounds, the ratio of dissolved to particulate lipids was much lower than in short-term deployments (Parrish 1998).

While poisoning reduced lipid dissolution by $9 \%$, this advantage may be outweighed by the considerable increase in variability in particulate lipid values (Figs. 8 \& 9). This greater variability, together with the greater lipid content in poisoned traps, also occurred throughout the 1996 sampling season, both at 80 and at $220 \mathrm{~m}$ (Ramos et al. 2003). The large and variable wax ester/steryl ester content in poisoned traps (Fig. 9) indicates one reason for this. We observed many more swimmers (mainly copepods) in poisoned samples and are unlikely to have been able to remove all animals, or parts thereof, from all samples.

\section{CONCLUSIONS}

The 1996 Conception Bay spring bloom started in mid-March at $0^{\circ} \mathrm{C}$ in the top $40 \mathrm{~m}$ of the water column. The $\mathrm{C}_{16}$ PUFA ratio reached a very high maximum of $56 \%$ in plankton 12 d later, thereafter this indicator of nutrient sufficient diatoms declined rapidly as surface nitrate concentrations decreased by $90 \%$. Forty days after the bloom started, deep water nutrient concentrations peaked and N:P ratios indicated regeneration from nitrogen depleted particles.

Total PUFA proportions reached a maximum in the plankton $25 \mathrm{~d}$ after the start of the bloom, and total and neutral lipid concentrations peaked $15 \mathrm{~d}$ later when the chlorophyll maximum had sunk to $50 \mathrm{~m}$. Samples of settling particulate matter were collected using unpoisoned sediment traps, which may underestimate lipid fluxes by $\sim 14 \%$ due to dissolution in the trap. In addition, there was evidence of admixture of lipid poor material near the bottom of Conception Bay from concentrations in 80 and $220 \mathrm{~m}$ traps and from integrated flux comparisons at each depth.

There were small changes in the average lipid class and fatty acid composition among the plankton and settling particle samples, suggesting some selective removal of PUFA between their synthesis in the photic 
zone and arrival at the benthos. There was little offset in the timing of maximum lipid concentrations among the net-tow, 80 and $220 \mathrm{~m}$ trap samples, indicating a rapid transfer. Overall, half of the total lipids, neutral lipids and PUFA passing through $80 \mathrm{~m}$ reached $220 \mathrm{~m}$, and the lipid and PUFA supply were more than 10 times that required by important amphipod and mysid populations in Conception Bay. This efficient flow of energy and essential nutrients remains to be compared with lipid requirements of other large abundant species in the depositional zone.

Acknowledgements. This work was funded by an NSERC Collaborative Project Grant. We thank J. Wells, M. Riehl, E. Hatfield and P. Warren for technical assistance.

\section{LITERATURE CITED}

Ackman RG (1986) WCOT (capillary) gas-liquid chromatography. In: Hamilton RJ, Rossell JB (eds) Analysis of oils and fats. Elsevier, New York, p 137-206

Ackman RG, Sipos JC, Tocher CS (1966) Some linear, iso, anteiso, and multiple-branched fatty acids of marine origin: analyses on packed and open-tubular gas-liquid chromatographic columns with particular reference to pristanic and phytanic acids. J Fish Res Board Can 24:635-650

Albers CS, Kattner G, Hagen W (1996) The compositions of wax esters, triacylglycerols and phospholipids in Arctic and Antarctic copepods: evidence of energetic adaptations. Mar Chem 55:347-358

Andreassen IJ, Wassmann P (1998) Vertical flux of phytoplankton and particulate biogenic matter in the marginal ice zone of the Barents Sea in May 1993. Mar Ecol Prog Ser 170:1-14

Asper VL, Deuser WG, Knauer GA, Lohrenz SE (1992) Rapid coupling of sinking particle fluxes between surface and deep ocean waters. Nature 357:670-672

Budge SM, Parrish CC (1998) Lipid biogeochemistry of plankton, settling matter and sediments in Trinity Bay, Newfoundland. II. Fatty acids. Org Geochem 29:1547-1559

Budge SM, Parrish CC (2003) FA determination in cold water marine samples. Lipids 38:781-791

Choe N, Deibel D, Thompson RJ (2003) Seasonal variation in the biochemical composition of the chaetognath Parasagitta elegans from the hyperbenthic zone of Conception Bay, Newfoundland. Mar Ecol Prog Ser 251:191-200

Colombo JC, Silverberg N, Gearing JN (1996b) Biogeochemistry of organic matter in the Laurentian Trough, I. Composition and vertical fluxes of rapidly settling particles. Mar Chem 51:277-293

Dunstan GA, Volkman JK, Barrett SM, Leroi JM, Jeffrey SW (1994) Essential polyunsaturated fatty acids from 14 species of diatom (Bacillariophyceae). Phytochemistry 35: 155-161

Dwyer KS, Parrish CC, Brown JA (2003) Lipid composition of yellowtail flounder (Limanda ferruginea) in relation to dietary lipid intake. Mar Biol 143:659-667

Fulco AJ (1983) Fatty acid metabolism in bacteria. Prog Lipid Res 22:133-160

Goñi MA, Yunker MB, Macdonald RW, Eglinton TI (2000) Distribution and sources of organic biomarkers in arctic sediments from the Mackenzie River and Beaufort Shelf. Mar Chem 71:23-51
Goodwin TW (1974) Carotenoids and biliproteins. In: Stewart WDP (ed) Algal physiology and biochemistry. University of California Press, Berkeley, p 176-205

Graeve M, Kattner G, Piepenburg D (1997) Lipids in Arctic benthos: does the fatty acid and alcohol composition reflect feeding and trophic interactions? Polar Biol 18: 53-61

Graf G (1992) Benthic-pelagic coupling: a benthic view. Oceanogr Mar Biol Annu Rev 30:149-190

Hall JM, Parrish CC, Thompson RJ (2002) Eicosapentaenoic acid regulates scallop (Placopecten magellanicus) membrane fluidity in response to cold. Biol Bull 202:201-203

Harrison PJ, Thompson PA, Calderwood GS (1990) Effects of nutrient and light limitation on the biochemical composition of phytoplankton. J Appl Phycol 2:45-56

Hayakawa K, Handa N, Kawanobe K, Wong CS (1996) Factors controlling the temporal variation of fatty acids in particulate matter during a phytoplankton bloom in a marine mesocosm. Mar Chem 52:233-244

Hayakawa K, Handa N, Fukuchi M (1997) Changes in the fatty acid composition of sinking particles during a phytoplankton bloom in the Austral summer in Breid Bay, Antarctica. Proc NIPR Symp Polar Biol 10:39-49

Hedges JI, Keil RG (1995) Sedimentary organic matter preservation: an assessment and speculative synthesis. Mar Chem 49:81-115

Henderson RJ, Hegseth EN, Park MT (1998) Seasonal variation in lipid and fatty acid composition of ice algae from the Barents Sea. Polar Biol 20:48-55

Kortzinger A, Schulz-Bull DE, Petrick G, Duinker JC (1994) Evidence for dissolution of fatty acids in sediment traps: Impact on flux estimates. J Geophys Res 99:3407-3415

Lee C, Hedges JI, Wakeham SG, Zhu N (1992) Effectiveness of various treatments in retarding microbial activity in sediment trap material and their effects on the collection of swimmers. Limnol Oceanogr 37:117-130

Milke LM, Bricelj VM, Parrish CC (2004) Growth of postlarval sea scallops, Placopecten magellanicus, on microalgal diets, with emphasis on the nutritional role of lipids and fatty acids. Aquaculture 234:293-317

Parrish CC (1987a) Separation of aquatic lipid classes by Chromarod thin-layer chromatography with measurement by Iatroscan flame ionization detection. Can J Fish Aquat Sci 44:722-731

Parrish CC (1987b) Time series of particulate and dissolved lipid classes during spring phytoplankton blooms in Bedford Basin, a marine inlet. Mar Ecol Prog Ser 35:129-139

Parrish CC (1998) Lipid biogeochemistry of plankton, settling matter and sediments in Trinity Bay, Newfoundland. I. Lipid classes. Org Geochem 29:1531-1545

Parrish CC (1999) Determination of total lipid, lipid classes, and fatty acids in aquatic samples. In: Arts MT, Wainman BC (eds) Lipids in freshwater ecosystems. SpringerVerlag, New York, p 4-20

Parrish CC, deFreitas ASW, Bodennec G, Macpherson EJ, Ackman RG (1991) Lipid composition of the toxic marine diatom, Nitzschia pungens. Phytochemistry 30:113-116

Parrish CC, Bodennec G, Gentien P (1994) Time courses of intracellular and extracellular lipid classes in batch cultures of the toxic dinoflagellate, Gymnodinium $\mathrm{cf}$. nagasakiense. Mar Chem 48:71-82

Parrish CC, Abrajano TA, Budge SM, Favaro YL, Helleur RJ, Hudson E, Pulchan K (2002) The marine environment: past and present inputs to Trinity Bay. In: Ommer RE (ed) The resilient outport: ecology, economy and society in rural Newfoundland. ISER Books, St. John's, Newfoundland, p 40-72 
Pomeroy LR, Wiebe WJ, Deibel D, Thompson RJ, Rowe GT, Pakulski JD (1991) Bacterial responses to temperature and substrate concentration during the Newfoundland spring bloom. Mar Ecol Prog Ser 75:143-159

Pond D, Harris R, Head R, Harbour D (1996) Environmental and nutritional factors determining seasonal variability in the fecundity and egg viability of Calanus helgolandicus in coastal waters off Plymouth, UK. Mar Ecol Prog Ser 143: $45-63$

Ramos CS, Parrish CC, Quibuyen TAO, Abrajano TA (2003) Molecular and carbon isotopic variations in lipids in rapidly settling particles during a spring phytoplankton bloom. Org Geochem 34:195-207

Redden AM (1994) Grazer-mediated chloropigment degradation and the vertical flux of spring bloom production in Conception Bay, Newfoundland. PhD thesis, Memorial University of Newfoundland

Reitan KI, Rainuzzo JR, Olsen Y (1994) Effect of nutrient limitation on fatty acid and lipid content of marine microalgae. J Phycol 30:972-979

Richoux NB (2004) Population dynamics and seasonal lipid cycles in hyperbenthic crustaceans from a cold-ocean environment (Conception Bay, Newfoundland): Mysis mixta (Mysidacea) and Acanthostepheia malmgreni (Amphipoda). $\mathrm{PhD}$ thesis, Memorial University of Newfoundland

Richoux NB, Thompson RJ, Deibel D, Parrish CC (2004a) Seasonal and developmental variation in the lipids of Acanthostepheia malmgreni (Amphipoda) from the hyperbenthos of a cold water environment (Conception Bay, Newfoundland). J Mar Biol Assoc UK 184:1189-1197

Richoux NB, Deibel D, Thompson RJ, Parrish CC (2004b) Seasonal changes in the lipids of Mysis mixta (Mysidacea) from the hyperbenthos of a cold water environment (Conception Bay, Newfoundland). Can J Fish Aquat Sci 61: 1940-1953

Shin KH, Hama T, Yoshie N, Noriki S, Tsunogai S (2000) Dynamics of fatty acids in newly biosynthesized phytoplankton cells and seston during a spring bloom off the west coast of Hokkaido Island, Japan. Mar Chem 70:243-256

Editorial responsibility: Otto Kinne (Editor-in-Chief), Oldendorf/Luhe, Germany
Sicko-Goad L, Andresen, NA (1991) Effect of growth and light/dark cycles on diatom lipid content and composition. J Phycol 27:710-718

Sieburth JMcN (1959) Antibacterial activity of Antarctic marine phytoplankton. Limnol Oceanogr 4:419-424

Skerratt JH, Nichols PD, McMeekin TA, Burton H (1995) Seasonal and inter-annual changes in planktonic biomass and community structure in eastern Antarctica using signature lipids. Mar Chem 51:93-113

Smetacek VS (1985) Role of sinking in diatom life-history cycles: ecological, evolutionary and geological significance. Mar Biol 84:239-251

Stead RA, Thompson RJ (2003) The effect of the sinking spring diatom bloom on digestive processes of the coldwater protobranch Yoldia hyperborea. Limnol Oceanogr 48:157-167

Sukenik A, Wahnon R (1991) Biochemical quality of marine unicellular algae with special emphasis on lipid composition. I. Isochrysis galbana. Aquaculture 97:61-72

Tian RC, Deibel D, Thompson RJ, Rivkin RB (2003) Modeling of climate forcing on a cold-ocean ecosystem, Conception Bay, Newfoundland. Mar Ecol Prog Ser 262:1-17

Tyler PA (1995) Conditions for the existence of life at the deep-sea floor: an update. Oceanogr Mar Biol Annu Rev 33:221-244

Viso AC, Marty JC (1993) Fatty acids from 28 marine microalgae. Phytochemistry 34:1521-1533

Volkman JK, Jeffrey SW, Nichols PD, Rogers GI, Garland CD (1989) Fatty acid and lipid composition of 10 species of microalgae used in mariculture. J Exp Mar Biol Ecol 128: 219-240

Weeks A, Conte MH, Harris RP, Bedo A and 10 others (1993) The physical and chemical environment and changes in community structure associated with bloom evolution: the Joint Global Flux Study North Atlantic Bloom Experiment. Deep-Sea Res II 40:347-368

Xu XL, Ji WJ, Castell JD, O'Dor RK (1994) Essential fatty acid requirement of the Chinese prawn, Penaeus chinensis. Aquaculture 127:29-40

Submitted: March 8, 2004; Accepted: August 31, 2004

Proofs received from author(s): January 11, 2005 
